\title{
Interpreting the Book of Revelation and Its Apocalyptic Implications for the 21st Century African Pentecostal Churches
}

\author{
Josephine Olatomi Soboyejo \\ Crowther Graduate Theological Seminary, Abeokuta, Nigeria \\ Email: joesoboyejo@hotmail.com
}

Received 20 June 2016; accepted 15 August 2016; published 18 August 2016

Copyright (C) 2016 by author and OALib.

This work is licensed under the Creative Commons Attribution International License (CC BY). http://creativecommons.org/licenses/by/4.0/

(c) (i) Open Access

\begin{abstract}
Revelation is unique as it combines three distinctive literary types: apocalypse, revelation and a letter. The apocalyptic writings are viewed as revealing heavenly secrets focusing on God's judgment of the wicked and his deliverance of the righteous. The book as a prophecy is a revelation from God that invites a response of trust and obedience though presented in the form of a letter from John to those Churches in the province of Asia. The book is not just a futurology but also a redemptive, historical and theological psychology for the Church's thinking throughout the age before Christ's final coming. John describes the imagery in a cryptic language and symbolism, which are very hard to understand. Eschatology is the primary theology of the book. The interpretation of Revelation has been a source of much controversy. Some held that it had a message only for the 1st century world; others maintain that the book is a prophecy to be fulfilled totally in the future. Undoubtedly, John spoke to the situation of his day that is also relevant for 21st century churches. The letters to the seven churches indicate a situation of crisis, probably brought on by Roman persecutions of the Christians. From this understanding, John painted a vision of God's final triumph over evil that has sustained many Christians in later eras. The 21st century churches in Africa are badly divided by sectarianism and are buried under avalanche of false doctrines that are incorporated in prosperity theology and syncretism. There is no indication through the witness of church members that faith offers any effective defense against sin's pervasive influence. The church ministers are embroiled in personal empowerment and churches have lost their power. This paper critically examines all these implications along the imagery of the seven churches in Revelation.
\end{abstract}

\section{Keywords}

Apocalypse, Imagery, Eschatology, Prophecy, Prosperity Theology, Syncretism, and Pentecostal Churches

Subject Areas: Philosophy 


\section{Introduction}

The "Revelation to John"-The Apocalypse is recorded in the book of Revelation. John developed significant theological themes in Revelation utilizing O.T. Scripture, Jewish interpretative traditions, and early Christian tradition. Irenaeus (ca. 180) dated Revelation to the time of reign of the Roman Emperor Domitian (A.D. 81-96), according to Hastings [1]. Tradition asserts that the apostle John wrote Revelation during his exile on Patmos. Some scholars do not accept this attribution because of the stylistic differences between Revelation and the other works attributed to John, "the Gospel and Epistles"; but John is clearly stated in the greetings and doxology. Four times the author identifies himself as John (1: 1, 4, 9; 22: 8). From as early as Justin Martyr in the second century A.D., it has been held that this John was the apostle, the son of Zebedee (Matthew 10: 2). Revelation is a panoramic symbolic vision given to the Apostle John in A.D. 95 to the seven Churches in Asia (Rev. 1: 19-21). In Revelation, John interprets the significance of the cross and resurrection for the future, be it near or distant. He declares their meaning for time and history until the end. God is on his throne (chap. 4); Christ has won the victory (chap. 5); God is at work in the midst of apparent chaos (seals, trumpets, and bowls). The true victors are those called out in Christ from every tongue, nation, and people (chaps. 5, 20). Although God's work in history has been hidden except to eyes of faith, the final stanza will reveal that history has truly been his story (chaps. $17,20)$. The victory won in history by the cross will be displayed in history by the return, and God will ultimately be revealed as all in all (chaps. 21, 22). John clearly understands himself and his readers as participants in God's kingdom. This confirms all that John has said up to this point with regard to the restoration of the kingdom. Participation in the kingdom brings tribulation and, therefore, requires patient endurance. This study is divided into six headings starting with an Introduction. The five other headings are: Keys to Understanding Revelation; Approaches to Interpreting Revelation; Apocalyptic and Epistolary Introduction; The Seven Churches in Revelation in the Context of $21^{\text {st }}$ Century African Pentecostal Churches; and The Apocalyptic Implications of John's Vision to the $21^{\text {st }}$ Century African Pentecostal Churches. The necessity and significance of this study are to look into the great lessons of John's visions as foundational for proclamation of the "true gospel' and peace in times of extreme persecutions. Gordon D. Fee and Douglas Stuart's How to Read the Bible, Book by Book (as discussed by Gordon and Stuart [2]) refers to the content of the Book of Revelation as:

A Christian prophecy cast in apocalyptic style and imagery and finally put in letter form, dealing primarily with tribulation (suffering) and salvation for God's people and God's wrath (judgment) on the Roman Empire.

The Jewish expectation foresaw the future kingdom as a place of peace and plenty. John makes it unmistakably clear that God's restoration of the kingdom - his fulfillment of the covenant, does not follow the lines of these expectations. John states the deep context of lives of Christians that are members of God's kingdom - his priestly people; but live in a world whose destructive and dehumanizing values, John sees as Fallen Babylon, a realm of being in rebellion against God. There is no other book of the Bible except the book of Daniel that has been subjected to the vagaries of interpreters as Revelation. The truths in the book of Revelation have their foundation in the prophecy in Daniel. There are two extreme cases, the futurists and the historical but the real method of interpretation must be independent of dogmatic pre-suppositions. Hastings Dictionary (Hastings [3]) says: "Revelation must be interpreted in accordance with the general principles applicable to apocalypses as a form of literary expression". The literary and critical analyses of Revelation do not coincide. The analysis does not differ fundamentally from that of other writers.

A book on theology of the New Testament written by George Eldon Ladd says the interpretation of Revelation has been the most difficult and confusing of all the books of the New Testament (as stated by Ladd [4]). Several distinct approaches emerged from the history of interpretation. Revelation's genre is apocalyptic though it has both epistolary and prophetic features. Ladd suggested in 1957 that Revelation be labeled "Prophetic-Apocalyptic". This may be due to the centrality of prophetic material; both the prophecy and the apocalyptic centre on future Salvation for the faithful and certain judgment for the unfaithful. While we may recognize the shadows of contemporary events in the Revelation, we must conclude that the elaborate symbolism of Jewish apocalyptic literature was employed in the interests of a prophetic forecast of the consummation of God's redemptive purpose, "Ladd and some other scholars' views" [5]. ${ }^{1}$ There are four Schools of interpretation of the Revelation. This paper examines the overview of the four: Preterist, Historicist, Idealist and Futurist.

${ }^{1}$ A few interpreters tried to adapt the Preterist view to a conservative approach. See A. Pieters, Studies in the Revelation of St. John (1943, 1954); R. Summers, Worthy Is the Lamb (1951). Also see G. R. Beasley-Murray in The New Bible Commentary (ed. F. Davidson; 1953); that combines the Preterist and Futurist methods. L. Morris, Revelation (1969); G. E. Ladd, Revelation (1972). 


\section{Keys to Understanding Revelation}

The symbolism of Revelation lies with the knowledge of Hebrew theology, the Law and the Prophets, (Isaiah 8: 20), and the ancient Jewish culture. Moses' vision saw the purpose from beginning to end with the coming of the Messiah and John's vision on the purpose of God (Elohim) from the end back to the beginning. In fact, some future events that have been prophesied in Revelation are repeats of past events. For example, the seven plagues that will be poured out on Mystery Babylon correspond with the seven last plagues that Moses and Aaron poured out on Egypt (Exodus 8 - 12). Many Biblical scholars have tried to interpret the vision of John with various methods, such as the contemporary historical method and the literary-critical method. Scholars cannot use philosophical methods to interpret a divine vision and revelation given to the Apostle John. These methods will not truly explain the interpretation of Revelation because this comes by the Holy Spirit (2 Pet. 1: 20-21). The contemporary historical method believes that the Jewish apocalypses are referring especially to the time or era of the writer. This method also believes in the literal interpretation of prophecy and that no spiritual or symbolical method should be used. The literary-critical method believes that Revelation was a series of visions, written at different times and places before and after the destruction of the temple at Jerusalem. Two great scholars: George Ladd and Dennis Bratcher describe the Bible as follows: Ladd's postulation— "The Bible is the word of God given in the words of men in history". Bratcher's postulation-“The Bible is God's word in human words". Revelation exhibits the conjecture of these scholars. Based on the postulation of Ladd and Bratcher, one can assume that:

A. Because it is God's word, the Bible has: (a) ongoing relevance, (b) authority, and (c) testimony to the nature of God. These cannot be investigated or proven; they are accepted by faith as given, so we cannot study the Revelation from any of these perspectives.

B. Because it is in human words, the Bible has: (a) historical and cultural particularity, (b) features of human creativity and expression, and (c) concerns common with human existence today. These can be investigated with various tools; this is the starting point of study. The process of doing so is described by two terms: exegesis and hermeneutics.

\section{Nature of the Book of Revelation}

The book as Apocalypse: An apocalypse is a very specific kind of literature with no modern equivalent. While there is only one OT apocalyptic book (Daniel) and one NT book that demonstrate some features of this type (Revelation), it was a common form of writing in the two centuries before and after the birth of Christ. There are several distinct features of apocalyptic writing:

1. It arises out of a historical context of great turmoil, persecution, and oppression. The prophets looked forward to God balancing the scales of justice within history; apocalyptic has given up on history and has become so pessimistic of change that it can only see God acting by bringing a radical end to history, destroying all evil, and beginning again with a new world.

2. It is presented in the form of visions, dreams, and other worldly journeys. Several features intend to communicate a sense of mystery, the revealing of secrets long hidden in the mists of the past. Therefore, most apocalyptic writing is written under the name of a long dead person of some reputation (Abraham, Moses, Enoch) who is instructed to keep the book for the "latter days", which, of course, would be the time the book was actually written. Also, there is often a guide to reveal the secrets or mysteries.

3. It is carefully crafted literature. It was not spoken (like prophetic sermons), but was composed. Therefore, it exhibits certain features of normal writing, such as structure, form, flow of thought, creative use of language, and so on.

4. Its images and symbols are forms of fantasy rather than reality, and its language is cryptic, metaphorical, and highly symbolic. These symbols are not drawn from our modern world, but from the language, experience, and cultural "pool" of the ancient world. The assumptions that underlie the symbols are likewise not those of a modern scientific worldview of the 21st century Western world, but those of the Ancient Near East of 2000 years ago. Strange multi-headed beasts, weird creatures, dragons, and odd combinations of normal images (locusts with scorpion's tails and human heads) are common ways of writing. It purposely presents a world that does not exist except as a means of communication.

5. It is a highly stylized and schematized way of writing. There are neat packages of time and event, all moving in a very ordered way. Sequences of numbers, people, or events are common. Numbers, especially, take on symbolic value, even to the point of ciphering (certain numbers standing for certain letters of the alphabet). There are frequent uses of certain numbers, such as 3, 7, and 12 (and multiples, such as 144,000). 
6. However, simply because writing exhibits some of the features of an apocalypse do not necessarily mean that its message or theology must conform to that genre. That would be to ignore both the dynamic of inspiration (God's word) and the creativity of the author/community of faith (in human words). While the book of Revelation is obviously modeled in some ways on the classic form of apocalyptic writings, the message of the book implies something far different than "traditional" apocalyptic writings.

The book as prophecy: Because Revelation is written in John's own name, it is related to OT prophecy, perhaps more closely than it is to the apocalyptic. But it is not prophecy in the popular (and incorrect) modern sense of "predicting the future". OT prophecy was overwhelmingly concerned with speaking God's message to people of the prophet's own time, interpreting God's will for them in light of the current historical events. The prophets were primarily "covenant mediators", calling the people to be faithful to God in the midst of the ups and downs of history.

1. In this sense, revelation is a message, not for the far future, but for the first century Church whose very existence was being threatened by persecution from both Romans and Jews. But as a message to the first century church, since we accept it as Scripture, it is also a "word" of God to the church today.

2. This relation to OT prophecy also underscores the fact that the Book of Revelation is related to a particular time in history, to a particular set of circumstances, and to particular people. This does not mean it is irrelevant for us today; it just means we cannot make it to address the issues we want it to address directly, without first understanding something about what it meant to the early church.

\section{Approaches to Interpreting Revelation}

Any keys to interpreting Revelation must be intrinsic to the text of the revelation itself or otherwise available to the original recipients from their own historical context, according to Fee and Stuart [6]. The rich and varied cultural context of the ancient world must be the frame of reference for interpreting the names and symbols of the book, but also with sensitivity to how creatively they are used in the book. The visions and symbols should not be pressed into allegory in which every detail has some meaning; most often the meaning is in the entire vision and its impact rather than every detail. Apocalypses do not intend to give a detailed chronological map of the future; the message is much more historically conditioned, and much more theologically oriented. Rather than a map of the future, it is an encouragement for the present.

\section{The Preterist Interpretation:}

Preterist (from Latin preter meaning "past") holds that through use of symbols and allegory, Revelation deals with events that were fulfilled in John's time and that it was written primarily to provide hope and comfort to the first century church persecuted by Rome. The symbols are drawn from ancient texts as well as contemporary culture to dramatize the plight of the church and to encourage its members in the face of troubled times. The "beast" (Rev. 13) is usually identified with the Empire of Rome, or a particular Roman emperor. While the book does deal with the future, in this view it is focused largely in the first century, and extrapolates and projects the first century experience of the church into the future. This view gained prominence in the 17th and 18th century as more knowledge of the history of the early church, as well as other apocalyptic writings from the period, came to light. Many modern scholars, especially liberals and those who deny that the Revelation predicts specific future events, hold the preterist view. Preterism understands certain eschatological passages, which are in the future, as having already been fulfilled. All biblical interpreters understand that certain prophecies have been fulfilled, but Preterists differ in that they interpret a greater portion of Scripture as already, have come to pass.

There are different types of Preterism resulting from differences in views as to which passages have been fulfilled and what events they fulfilled. Mild or Partial Preterism holds that most of the prophecies of Revelation were fulfilled in either the fall of Jerusalem (A.D. 70) or the fall of the Roman Empire (A.D. 476), but the Second Coming of Christ is futuristic, "Johnson Allan and Ice Thomas on what is Preterism?, written on spirit and truth website" [7] [8]. This form of Preterism is orthodox and is the most frequent view encountered today. Moderate Preterism has become mainstream Preterism as it appears to be the most widely held version of Preterism today. In addition to R.C. Sproul, some well-known moderate Preterists include Kenneth L. Gentry, Jr., Gary DeMar, and the late David Chilton (who converted to full Preterism after all his books were published). Full, extreme, or consistent Preterism holds that all the prophecies of Revelation are already fulfilled, that we are currently living spiritually in the "new heavens and new earth" and denies a future bodily return of Jesus. Extreme Preterists believe that "the second coming must have already occurred, since it was one of the things pre- 
dicted in the Old Testament, which had to be fulfilled by the time Jerusalem was destroyed". This means there will never be a future second coming, for it already occurred in A.D. 70. Further, there will be no bodily resurrection of believers, which is said to have occurred in A.D. 70 in conjunction with the second coming. Full Preterists believe that we now have been spiritually resurrected and will live forever with spiritual bodies when we die. Full Preterists say, we are now living in what would be called the eternal state or the new heavens and new earth of Rev. 21-22. Proponents of this view include the originator of full Preterism, J. Stuart Russell, Max R. King and his son, Tim, David Chilton, Ed Stevens, Don K. Preston, John Noe, and John L. Bray. The purpose of the book to Preterists is to encourage Christians to endure because their persecutors assuredly will be judged.

\section{The Historicist Interpretation - (The Road Map of World History)}

Historicist views Revelation as a symbolic or allegorical prophetic survey of church history from the first century up to the second coming of Christ and this was the view espoused by most of the "reformers". This view dominated Protestant for centuries. Revelation basically deals with all of human history. The meaning of the symbols is to be found in the events of history. Some hold that the book deals more with the period prior to the present, some see it as unfolding in the present, and some emphasize the future more. The entire book is a symbolic account of the whole scope of world history, with the "beast" identified with various historical figures or people, from the Saracens, to Mohammed, to the Pope, to Adolph Hitler. This view arose in the middle Ages, and was adopted by most of the reformers in the 16th century, including Martin Luther who popularized the idea that the "beast" was the Roman Catholic Pope. In turn, Catholic theologians were convinced that Luther was the "beast". Historicist view has been largely discounted, as it does not adequately address the prophecy in Revelation. The historicist view is reflected in most of the "older" commentaries including the works of John Knox, Martin Luther, John Calvin, John Wesley, Jonathan Edwards, George Whitefield, C. H. Spurgeon, Matthew Henry, Adam Clarke and Albert Barnes An example of a historicist interpretation is the belief that the strong angel of Rev. 10 symbolizes the reformation and that the harlot in Rev. 17 represents the Roman Catholic Church, an interpretation that the plain reading of the text simply does not agree. The historicist system of interpretation understands Revelation as setting forth the major events of Christian history spanning the time of John until the present. Proponents of this method have tended to take Rev. 2-19 including the seals, trumpets, and bowls as well as the interludes, as prophetic of salvation history, that is, the development of church history within world history. This view has also been called the Classicist. The Classicist view interprets Revelation as the symbolic history of the "Church" from apostolic times to the return of Christ and judgment. It denies a literal thousand-year reign of Christ, and makes the predictions more general in their application through history. This view can lead to subjectivism and widely differing opinions as to the meaning and fulfillment of the symbols.

\section{The Idealist Interpretation: (Eternal Principles)}

The Idealist maintains that Revelation is not predictive prophecy, but a symbolic portrait of the cosmic conflict between the forces of good and evil. In this view, Revelation becomes merely a collection of stories designed to teach spiritual truth. Some refer to this method of interpretation as "Spiritual". Mounce and Osborne provide a good summary of the idealist approach to interpreting Revelation, "Mounce views are expressed in his book [9]". Idealist proponents hold that Revelation is not to be taken in reference to any specific events at all but as an expression of those basic principles on which God acts throughout history. The idealist approach continues the allegorical interpretation, which dominated exegesis throughout the medieval period and still finds favor with those inclined to minimize the historical character of the coming consummation. This popular approach argues that the symbols do not relate to historical events but rather to timeless spiritual truths. As such, it relates primarily to the church between the advents, that is, between Christ's first and second comings. Thus it concerns the battle between God and evil and between the church and the world at all times in church history. The millennium in this approach is not a future event but the final cycle of the book, describing the church age. The Idealist employs allegorical interpretation to reduce Revelation to a symbolic exhibition of good versus evil. The more moderate form of allegorical interpretation, following Augustine, regards Revelation as presented in a symbolic way the total conflict between Christianity and evil or, as Augustine put it, "the City of God versus the City of Satan". Idealist Calkins summarizes Idealism in five propositions: It is an irresistible summons to heroic living; the book contains matchless appeals to endurance; It tells us that evil is marked for overthrow in the end; It gives us a new and wonderful picture of Christ; and the Apocalypse reveals to us the fact that Christ is the author and reviewer of moral destinies of men.

\section{The Futurist Interpretation: (A Blueprint of the End Times)}

A literal reading of prophecy will primarily produce a "futurist” interpretation. Thus futurists interpret Reve- 
lation 4-22 as predictive of future, end time historical events preceding during and after the return of Jesus Christ. Futurist usually Premillennial and Amillennialists spiritualize the 1000 years; postmillennialists spiritualize the resurrection which precedes it, millennial kingdom on earth, followed by the creation of a new heaven and new earth. Variations of this view were held by the earliest expositors, such as Justin Martyr (d. 164), Irenaeus (d. c. 195), etc. This futurist approach has enjoyed a revival since the 19th century and is widely held among evangelicals today. The approach to interpreting Revelation that has gained perhaps the widest exposure of all systems of interpretation in recent times is the futurist interpretation. This is a result of a number of seminaries in the recent past, that have championed a literal interpretative approach to all of Scripture within a framework that understands related Old Testament passages and promises involving Israel, and which distinguishes between Israel and the Church. The futurist interpretation is the basic interpretive framework behind the hugely popular left behind series of novels by authors Tim LaHaye and Jerry Jenkins. Futurism derives from the consistent application of literal hermeneutics, he Golden Rule of Interpretation, across the entire body of Scripture, including Revelation, according to Ice Thomas, Tim LaHaye and other scholars on spirit and truth on-line commentary on Revelation [8] [10]. Contrary to the claims of many of its critics, it is not a priority view, which is imposed on the text. As evidenced by the testimony of the early Church, futurism is the most natural result of a plain reading of the text and the way that most unbiased readers would understand the book on their first reading. Futurism gets its label from its refusal to see unfulfilled passages as having been fulfilled by approximately similar events in the past. Hence, it holds that many of the events in the book of Revelation await future fulfillment.

\section{Apocalyptic and Epistolary Introduction}

\section{Apocalyptic Introduction (Revelation 1: 1-3)}

The full implications of John's apocalyptic introduction can only be fully grasped when the reality of his vision begins to become clear. For his audience, however, both Jewish Christians, and Gentiles socialized to the Jewish-Christian tradition, John indicates that Jesus is the Messiah in whom God is revealing the fulfillment of His purposes for His people. John also indicates that God's fulfillment, begun in Jesus, is continuing to be played out according to God's purposes. Those who participate fully in what God is doing (those who listen and obey) will experience the blessings of becoming God's people in His fulfilled purposes. The apocalyptic introduction as at today is almost incomprehensible outside the full sweep of John's vision. The larger vision reveals that God has fulfilled the purposes; He sets forth in His covenant to Abraham (Gen 12: 2-3). There, God promised that all the nations of the earth would be blessed through Abraham's descendants. We will see that the people of God are those redeemed from every tribe, nation, tongue, and people (5: 9, 7: 9). God has also fulfilled the purposes He sets forth in His covenant with Moses, that His people would be a kingdom of priests (Exodus 19: 6). It is clear that in Jesus death and resurrection, the Messiah has made believers a kingdom of priests (1: 6). Gentiles are now called to live their lives in the world as members of God's kingdom and as priests of God in such radical obedience to God (having the Word of God) that they may become like Jesus in the world. To live as members of God's kingdom is to incarnate the values, perspectives, and relationships of God's kingdom into our daily living. "To be priests of God is to be agents of God's redeeming, healing, liberating, transforming grace to a broken and hurting world", "Dr. Mulholland's class lecture [11]”.

\section{Epistolary Introduction (Revelation 1: 4-8)}

For John's audience, steeped in or well acquainted with the Jewish expectations of the restoration of the Kingdom, the epistolary introduction is a profoundly radical statement. John clearly infers that in Jesus as Messiah, God has fulfilled His promise through the prophets to His people to restore the kingdom to Israel. The focal element is that the death of the Messiah has cleansed Israel from her sins and made her God's kingdom of priests in fulfillment of the purpose of the Covenant (Exodus 19: 6). The authentication of this reality is the resurrection of Jesus, the faithful martyr, the unmistakable sign that the restoration has begun. God's restoration of the kingdom extends far beyond Israel's limitation of it to Jews only. We Gentiles have also been incorporated into God's kingdom as priests. We are now called to live as faithful citizens of God's new realm of being, looking expectantly for its ultimate consummation in the return of Jesus.

\section{The Seven Churches in Revelation in the Context of $21^{\text {st }}$ Century African Pentecostal Churches}

Since every church in every age face from its culture similar pressures to accommodate the world's values, 
perspectives and life styles, it is then presumed that John's vision speaks to the church throughout the ages. The historical grounding in the culture of the Roman cities is basic to understanding the messages the churches receive from Jesus. However, each letter to an individual church is to be heard by all the churches. In some sense, therefore, the letters are to all the churches. Since all churches in John's day would face the same pressures and temptations as the seven addressed, it is reasonable to presume the vision is for them as well, "Ramsay discussed the letters to the seven churches of Asia [12]". The seven churches are ordered in an interesting pattern of "Perfect" Churches, "Problem" Churches and "Perverse" Churches:

(1) Ephesus: Problem

(2) Smyrna: Perfect

(3) Pergamum: Problem

(4) Thyatira: All Three

(5) Sardis: Perverse

(6) Philadelphia: Perfect

(7) Laodicea: Perverse

The Church in Ephesus (Revelation 2: 1-7)

The Ephesians' church was working diligently and enduring pressures from its Fallen Babylon context. The church was also very careful not to allow any "infection" from Fallen Babylon to enter its fellowship. They had some kind of test to ensure that no one got into the community, if they were tainted by Fallen Babylon. The church was not denying their allegiance to Jesus and had not become tired of being faithful citizens of New Jerusalem. They were not, however, reaching out to their world with the liberating, healing, cleansing, and transforming reality of God's grace in Jesus. The church was profoundly orthodox but no longer evangelistic. Jesus praises their orthodoxy, but indicates that the evangelistic failure has the church on the verge of ceasing to be a community of God's people (their lamp stand is about to be removed). If the analysis of the problem in Ephesus is correct, then orthodoxy and evangelism are the inseparable foci of a healthy church. Both must be kept in dynamic balance. Evangelism without orthodoxy becomes a tolerant pluralism and results in a community formed around diffuse human values and criteria. Orthodoxy without evangelism becomes a cold, harsh legalism and results in a community formed around debilitating “do's and don'ts". Sound orthodoxy and fervent evangelism with discipleship result in a community of faith whose growing wholeness of life is a powerful witness of the cleansing, healing; liberating life in Christ to a soiled, wounded, imprisoned world.

\section{Smyrna (Revelation 2: 8-11)}

John's vision makes it clear that faithfulness may result in suffering at the hands of the Fallen Babylon world but how relevant is this for $21^{\text {st }}$ century African Pentecostal churches when more Christians have been martyred in the $20^{\text {th }}$ century than the preceding nineteen. Christians will always be called to account for their faith and the genuine incarnation in their lives. The values and perspectives of God's Kingdom are always a threat to the dehumanizing perspectives and destructive values of the Fallen Babylon world. Jesus' word to Smyrna is in sharp contrast to those who proclaim a gospel of prosperity. Laodicea represents a perfect example of a "prosperity" church; in contrast Smyrna from the Revelation's account was one of the faithful churches, a community of God's people living out their lives as disciples of the kingdom. The terms associated with this faithful church are not comfortable; suffering, poverty, blasphemy by others, being afraid, prison, being put to the test, facing death etc. These are not terms or experiences that would induce people to sign in for the Christian pilgrimage. Very often we have "domesticated" the Gospel to make it palatable to those of our Fallen Babylon world. It is imperative to be faithful citizens of God's New Jerusalem no matter what the cost. It is costly to follow Christ and that is why He asked people to carry their crosses and follow Him.

\section{Pergamum (Revelation 2: 12-17)}

Like the Ephesians' church (2: 1-7), the Pergamum church receives praise from Jesus for aspects of its faithfulness. It has even held fast in the face of a persecution in which one of its members was martyred. Like Ephesus, it seems to be a faithful church, living as citizens of God's New Jerusalem in the midst of the pressures of their Fallen Babylon world. Also like Ephesus, the Pergamum church has problems. Their problems differ from Ephesus. In Ephesus, the entire church seems to be involved in its cold orthodoxy. In Pergamum there are two groups. One group is verging on apostasy with its advocacy of eating food offered to idols and spiritual fornication, participating in the worship of other gods. The rest, who appear not to participate in this activity, are tolerant of those who do. In a culture similar to the present age, where toleration has become the primary virtue, it is easy for the community of faith to "Christianize" tolerance and allows all sorts of destructive perspectives and 
behaviors into its fellowship. It is evident that the surrounding culture cultivates and promotes toleration as the ultimate level of maturity and caring, no one wants to be accused of being "intolerant". This is even more the case when we consider that Ephesians'-type churches that tend to manifest a brand of intolerance that rightly brings the world's scorn and ridicule down upon them. If the Ephesian church represents the intolerance of cold orthodoxy, the Pergamum church represents the toleration of mild heterodoxy.

\section{Thyatira (Revelation 2: 18-29)}

Thyatira is the central church of the seven and embodies all the three conditions. Only by highly contrived constructs of history can this be made to be an outline of church history. The first three churches are in the pattern, problem church, perfect church, and problem church. The last three are in the pattern, perverse church, perfect church, and perverse church. Thyatira appears to combine all three types: perfect, problem, and perverse. Not only does Jesus praise them for their faithfulness, he also indicates the constant improvement in all these things (2: 19). Some of them, however, are perverse, following the apostasy of "Jezebel". These will return to spiritual impotency if they don't repent. Some are problematic, tolerating her and her followers. These are the ones who, while they have love, faith, service, and patient endurance, are warned for their toleration of Jezebel and her followers. Some are perfect, not following this false teaching. These are the ones who are exhibiting constant improvement in all things, and of whom Jesus asks nothing more. The more we understand what is represented in these churches, the more we see that John's vision speaks strongly to the church in every age. In many "mainline" denominations in $21^{\text {st }}$ century African Churches, there is a three-way division. On the one side are those who, at various levels and in diverse ways, seek to live lives of faithful Christian discipleship. These are often labeled "conservatives", or "fundamentalists", or "evangelicals". On the other side are those who, in equal diversity, adopt various apostate or heretical perspectives and behaviors. These are often labeled "liberals", or "radicals". In the middle are those who, for various reasons, ally themselves with neither side but "tolerate" the extremes of both sides for the sake of preserving the myth of structural or denominational "loyalty" or "unity”.

\section{Sardis (Revelation 3: 1-6)}

With the exception of a few faithful souls, the church at Sardis is in dire straits. They are so spiritually dead that they are on the verge of having their name erased from the Book of Life. Unlike the previous "problem" churches, repentance is not enough. They need to return to the essentials of their experience of redemption, and once again begin to live out that reality in their life. The crucial problem with the church in Sardis is that they have a reputation for being alive. This church had, "exciting" worship that appealed to the tastes of the culture but was dead to the genuine awe and humility of true worship. It was like a church alive to "entertaining" programs for children, youth, and adults that confirmed the status quo but was dead to the transforming grace of God. Sardis could have been a church alive with "socially aware" attitudes and activities whose deadness sought to legitimize personal and social aberrations rather than witness to the liberating power of God. Was this a church so "alive" with the world's perspectives, values, and behaviors that it was "dead" to those of the kingdom? (M. Robert Mulholland Jr.). There are many such Sardis-type churches in the world today that are easily identifiable.

Philadelphia (Revelation 3: 7-13)

Philadelphia was founded either by Eumenes II (197-159 B.C.) or Attalus II (Philadelphos 159-138 B.C.) It, too, passed into Roman control through the will of Attalus III in 133 B.C. As the center of a fertile vine growing area, the worship of Dionysus, the god of wine, was one of the major religious expressions. The church in Romania under communist rule was hounded, persecuted, imprisoned, tortured, martyred. Yet it was the church that triggered the movement that ultimately brought down the brutal, dictatorial regime. After the fall of the regime, on the bulletin board of the church that had been at the center of the storm appeared this announcement: The Lamb Won! This church knew what it was to be a Philadelphia-type church, true followers of the powerless Lamb that was slain. Most often, a faithful group of disciples had to withstand not only the pressures of the state, but also the power of a state church. In the words of Kenneth Leech, [13]:

Following the leadership of Jesus, his Church needs to stand as a sign of contradiction and of conflict, affecting and, as it were, upsetting through the power of the Gospel, mankind's criteria of judgment, determining values, points of interest, lines of thought, sources of inspiration, and models of life which are in contrast with the Word of God, and the plan of salvation.

Always, at some level of its life, the church lives against the grain of its culture. When it does so, it loses the 
power and prestige that comes with being a supporter of the status quo. There is a powerful temptation to "play the world's games," to let the world set the agenda, to operate by the world's rules so as to be an "influence for God" in the world. If we give up, individually or corporately our positions of influence, prestige, and power in the world, we cannot advance the kingdom of God. But in a kingdom established by a crucified Messiah, life comes through death, victory through defeat, strength through weakness, power through powerlessness. The world today needs more churches like Philadelphia-type.

Laodicea (Revelation 3: 14-22)

Laodicea church thinks she is rich, has prospered, and need nothing more. Here is a "prosperity gospel" church. What Jesus says to the Laodicean church should give pause to the proclaimers and adherents of the "prosperity gospel". The Laodicean Church is a Church almost immersed in the perspectives and values of its culture. The norms of the culture have become the standards of the congregation by which they evaluate the church's life. They fit comfortably and smoothly into the ebb and flow of their world. They do not stand out in the warmth of their compassion for the marginalized, their concern for institutionalized injustice, and their zeal to be agents of God's transforming grace in their broken and hurting world. They are not "hot"; neither do they stand out in their coolness toward the destructive and dehumanizing values of their Fallen Babylon world, their resistance to corruption, and their refusal to follow the idolatries of their culture. Jesus tells such a church that true "riches" come only through "fire". On the one hand, this is the fire of God's holiness that purges the soul of all impurities, refines habits, burnishes behaviors, purifies relationships and enables people to be in the presence of God's love, truth and grace in the world Jr., "Mulholland oral lecture" [11]. On the other hand, it is the "fire" of adversity and opposition that reveals the weakness of our reliance upon our own strength, that probes our dependence upon popularity, power, or possessions as the source of our identity and signs of our success, that drives us into the heart of God and leads us to entrust our entire being to Him. Charles Wesley sings, "Refining fire, go through my heart, illuminate my soul; scatter thy life through every part, and sanctify the whole". In contrast to the luxurious black garments of Laodicea, Jesus counsels the church to buy from him white garments to cover the shame of their nakedness. Unless Christians are "clothed with Christ", they stand vulnerable and exposed to the powers of the world's values and perspectives. The "body" becomes wounded by the manipulations of others. It becomes scarred by rejection, broken by abuses, crippled by destructive relationships, deformed by dehumanizing structures of life. But when clothed with a white garment in a world clothed in black, they stand out. Instead of participating in dehumanizing economic, political, or social structures that marginalize and dehumanize others, they become those through whom God affirms the full humanity of others. G. J. Chesterton said; "the first time he read the Sermon on the Mount, he thought it was all upside down but, on a more reflective reading, he came to realize that it was the world that was 'upside down'”. Christ calls his followers to a divine way of seeing the world, themselves and others.

\section{The Apocalyptic Implications of John's Vision to the 21st Century African Pentecostal Churches}

Late David B. Barrett in his book claimed that classical Pentecostalism constituted the largest unit in the Protestant family, as discussed by Barret [14]. Today's Pentecostal is involved in excessive formalism and preoccupation with externals in much of official Christianity rather than stress personal holiness rooted in scriptural-oriented public and private prayer. The $21^{\text {st }}$ century African Pentecostal churches are like Thyatira, the central church of the seven that embodies all three conditions-Perfect, Problem, and Perverse. They are more problematic and perverse churches in Africa. Most of the outward contradictions start from allegations of endemic and audacious corruption, domination, exploitation, oppression, discrimination, marginalization, bigotry, nepotism, occultism, personal empowerment, and leadership power. These variants have allowed intrusions into Christendom in the $21^{\text {st }}$ century wrecking havoc to the Christian faith. Some of the intrusions are listed below; five of them are discussed in details:

- Prosperity Preaching/Theology;

- Seeker Sensitivity;

- Accountability and Corruption;

- Embezzlement and mismanagement of funds and resources;

- Leadership and Succession problems in the Church;

- Lack of peaceful co-existence among various denominations and other religions; 
- Gender discrimination;

- Proselytization and religious propaganda;

- Religious fundamentalism and violence;

- Religious persecution, violation of human rights and denial of religious liberty;

- Religious pluralism and secularism;

- Problems of Religious politics and dominance;

- Rise of new religions, Cults and Occultism;

- Divorce;

- Gay/Lesbianism; and

- Modern Psychology.

Prosperity Preaching/Theology

Prosperity preaching known as prosperity gospel is sometimes referred to as Prosperity theology. The health and wealth gospel or the gospel of success ${ }^{2}$ is a religious belief among some Christians that financial blessing is the will of God for them, and that faith, positive speech, and donations will increase one's material wealth. Orthodox Christianity understands faith to be total surrender, believe and trust in Jesus Christ, the truth of His teaching, and the redemptive work He accomplished at Calvary, but prosperity preachers and their churches promote a different doctrine. In his book, The Laws of Prosperity, Kenneth Copeland wrote, [15]:

Faith is a spiritual force, a spiritual energy, a spiritual power. It is this force of faith, which makes the laws of the spirit world function. There are certain laws governing prosperity revealed in God's Word. Faith causes them to function.

This is not only faulty but also heretical understanding of "Faith". Later in the same book Copeland wrote:

If you make up your mind ... that you are willing to live in divine prosperity and abundance, ... divine prosperity will come to pass in your life. You have exercised your faith. [16]

According to prosperity theology, faith is not a theocentric act of the will, or simply trust in God; rather it is an anthropocentric spiritual force, directed at God. Indeed, any theology that views faith solely as a means to material gains rather than the acceptance of heavenly justification must be judged faulty. There are many reasons the prosperity gospel is damaging the continent of Africa today but this paper examines five of those reasons:

- It is mixed with occultism birthing cultic theology:

Before Christianity came to Africa people visited witch doctors and sacrificed goats or cows to get prosperity; they poured libations on the ground so the gods would hear their prayers. Today similar practices continue because the prosperity preachers have replaced the Ifa priests. There are stories of church ministers who buried live animals under the floor of their churches to win people's favour. The people who follow these prosperity preachers are reminded that their promised windfall won't materialize unless they give large donations of money or properties.

\section{- It drives greed by fueling self-indulgence:}

The prosperity preacher teaches people to focus on getting, not giving. Church members are continually urged to sow financial seeds to reap bigger rewards. In Africa, Christian revivals are dedicated to collecting offerings in order to achieve wealth. Preachers tell their followers that spirituality is measured by their physical prosperity. This greed preached from the pulpit spreads like plague in God's house.

- It promotes conceit:

The greedy atmosphere in prosperity churches has produced arrogance and a warped style of leadership. A Kenyan, Gideon Thuranira, editor of Christian Professional magazine, called these men "church preneurs". They plant churches not because they have a burden to reach lost souls but because they see different currencies of the world when they fill an auditorium with chairs. The most successful prosperity preacher is the most dangerous because he can convince a crowd that Jesus died to give you a Lexus, airplane or several mansions. In Nigeria, there are many cases of theses preachers accumulating fabulous wealth and live in opulence as their followers become poorer.

- It works against the formation of Christian character:

The prosperity gospel is a poor imitation of the true gospel because it leaves no room for brokenness, suffer-

${ }^{2}$ Pejorative nicknames have been attached to the theology, including "name it and claim it” and "blab it and grab it”. 
ing, humility or delay. Prosperity preachers promise instant results and overnight success; if you don't get your breakthrough, it is because you are not giving enough offering. Jesus calls us to deny ourselves and follow Him; prosperity preaching calls us to deny Jesus and follow our materialistic lusts. Some church ministers are so set on getting rich; they cannot go through the process of discipleship that requires self-denial. Spiritual formation has been jettisoned for materials' formation.

\section{- It keeps people in poverty:}

The government of Malawi was once under international scrutiny because of fraud carried out by top leaders. The so-called "Cashgate" scandal is that professing Christians in the administration of President Joyce Banda were implicated. One of these people stole millions of kwacha from the government and hid the cash in a teddy bear! Most people today in Malawi live on less than $\$ 1$ a day, yet their leaders have been known to buy fleets of cars and huge plots of land with money that was not theirs. Sadly, the prosperity gospel preached in Malawi has encouraged pastors and leaders to follow the same corrupt pattern. As a result, God's people have been financially exploited. The same thing happened in Nigeria during the administration of Goodluck Jonathan when the president of Christian Association of Nigeria was implicated in the seized cash from his plane by South African government. Jesus described false prophets as wolves in sheep’s clothing. Churches have been growing rapidly in many parts of Africa today, yet sub-Saharan Africa is the only region in the world where poverty has increased in the past 25 years. So according to the statistics, the prosperity gospel is not bringing prosperity! It makes their followers poorer so it is a flawed message!

\section{Seeker Sensitivity:}

The attempted integration of self-esteem into Christianity has not only influenced the theology of Christian counselors but has also distorted the mission and proclamation of many evangelical and mainline Protestant churches. Influenced by the Church Growth Movement, church leaders ask the questions: If the people in our community are seeking a sense of self-worth and self-esteem, how can we reach them? How can we be sensitive to the desires of these seekers? How can we produce a Sunday morning service that will allow these poor people with their wounded hearts and victimized lives to go home feeling good about them-selves? The preaching of the Law, the doctrine of original sin, the confession of sins, the preaching of a bloody cross as the payment for human sin has been forsaken. As a result, in the thinking of many evangelical "Christians" today, Jesus is no longer primarily the suffering Savior who gave his life for the forgiveness of our sins. Rather, it is prosperity preaching; gospel of feeling good about self and be happy. So, instead of gathering together in contrition and repentance, acknowledging sin and hearing the Good News of the forgiveness of sins in Jesus Christ, Christians today often hear sermons on politics, morals, values, and principles for living the alleged Christian life. The integration of the self-esteem concept into Christianity has produced devastating results.

\section{Accountability and Corruption:}

The Bible is good for rebuking and training in righteousness - 2 Tim 3: 16; this verse is no longer used as a guide for accountability and corruption in the house of God. The foundation of Spiritual growth is the understanding of God's word. Churches grow best as they combine Obedience to the Bible in the context of close "Accountability Relationships"-Galatians 5: 16-26. Christians should be known by the good works they do within the community. What service project or act of kindness could you do as an individual, as a group or with others ministries of the church in order to demonstrate Christ's love in a tangible way? But in reality, church overseers and leaders push their congregation to bring money called harvest into the house of God without a care to the source of the money. Even some church leaders convert Church funds to personal uses. Congregation becomes leaner but the Pastor fatter. Monetary issue has divided many ministries and some leaders have sold their souls to the devil due to corrupt enrichment. This challenge is for theologians to proclaim to all the teachings of Jesus Christ on wealth accumulation and speak openly against corruption. Church Leaders must be accountable and try to emulate the Master.

\section{Embezzlement and Mismanagement of Funds and Resources:}

These social vices have crept into Christendom; the theologians must preach against them and eradicate the vices before they consume the Church.

Leadership and Succession Problems in Church:

Like change in political leadership, change in religious leadership sees it as "do or die" affair. They use blackmail, kill or destroy those they consider as obstacles to achieving their goals. The elections into religious leadership positions are defaced with use of charms, manipulations and verbal assaults that affect the spiritual lives of the church members after elections. Religious leaders use politics and religions as potent tools of deceits 
for Power. A church that is supposed to be led by the Holy Spirit has put the Holy Spirit in the backbench while inordinate ambition takes over the front row. People are no longer waiting to hear from God or being called by God. Church Ministries are now the alternative to unemployment and retrenchment; and the service of God is being treated like any employment. Spiritualism is no longer in effect; some even resort to consulting Ifa Priests', Alfas'; use of Talisman and any type of Traditional armour to gain upper hand in the Church of God. There are cases of in fighting throwing overboard the basic teaching of Christ in loving one-another.

\section{Conclusion/Recommendations}

John's vision makes it very clear at several points that all citizens of New Jerusalem started as citizens of fallen Babylon. Through the cross, the Lamb ransomed people for God from every tribe, language, people and nation (5: 9). John then sees this group standing before the throne of God and the Lamb and worshipping (7: 9-12). Whenever the church forgets that the Gospel is for the world, it forgets its primary purpose in the world. The church is not only the proclaimer of the Good News, but also called to be the incarnation of the Good News. The Good News for citizens of Fallen Babylon are that there is a way of life, a mode of being, a realm of existence in which healing for brokenness, forgiveness of sin, cleansing of ungodliness, liberation from bondage, and transformation to wholeness can be found. The true gospel is that of "Salvation". Salvation is the work of God, and for God in mercy has withheld the deserved punishment for our sins because Christ has paid the penalty for human beings (Romans 9: 10-15, Titus 3: 4-7).

\section{References}

[1] Hastings, J. (2001) Hastings Dictionary of the Bible. Hendrickson Publishers Inc., New York, 797.

[2] Fee, G.D. and Stuart, D. (2002) How to Read the Bible Book by Book. Zondervan, Grand Rapids, Michigan, 426.

[3] Hastings, J. (2001) Hastings Dictionary of the Bible. Hendrickson Publishers Inc., New York, 798.

[4] Ladd, G.E. (1993) A Theology of the New Testament. Revised Edition, William B. Eerdmans Publishing Company, Grand Rapids, Michigan, 670.

[5] Ladd, G.E. (1993) A Theology of the New Testament: Revised Edition. William B. Eerdmans Publishing Company, Grand Rapids, Michigan, 672.

[6] Fee, G.D. and Stuart, D. (2002) How to Read the Bible Book by Book. Zondervan, Grand Rapids, Michigan, 209.

[7] Johnson, A.F. (1966) Revelation: The Expositor’s Bible Commentary. Zondervan Publishing House, Grand Rapids.

[8] Ice, T. (2003) What Is Preterism? In: LaHaye, T. and Ice, T., Eds., The End Times Controversy Eugene, Harvest House Publishers, Eugene, OR.

[9] Mounce, R.H. (1977) The Book of Revelation. William B. Eerdmans Publishing Co., Grand Rapids, MI.

[10] Woods, A. (2003) Revelation 13 and the First Beast. In: LaHaye, T. and Ice, T., Eds., The End Times Controversy, Harvest House Publishers, Eugene, OR.

[11] Mulholland Jr., M.R. (1990) Oral Lecture. West Africa Theological Seminary (WATS), University of Nigeria, Nsukka.

[12] Ramsay, W.M. (2004) The Letters to the Seven Churches of Asia. Kessinger Publishing, LLC, Whitefish, Montana.

[13] Leech, K. (1985) True God: An Exploration in Spiritual Theology. Sheldon Press, London, 391.

[14] Barrette, D. (2001) World Christian Encyclopedia: A Comparative Survey of Churches and Religions in the Modern World. 2nd Edition, Oxford University Press, New York.

[15] Copeland, K. (1974) The Laws of Prosperity. Kenneth Copeland Publications, Fort Worth, Texas, 19.

[16] Copeland, K. (1974) The Laws of Prosperity. Kenneth Copeland Publications, Fort Worth, Texas, 41. 
Submit or recommend next manuscript to OALib Journal and we will provide best service for you:

- Publication frequency: Monthly

- 9 subject areas of science, technology and medicine

- Fair and rigorous peer-review system

- Fast publication process

- Article promotion in various social networking sites (LinkedIn, Facebook, Twitter, etc.)

- Maximum dissemination of your research work

Submit Your Paper Online: Click Here to Submit

Contact Us: service@oalib.com 